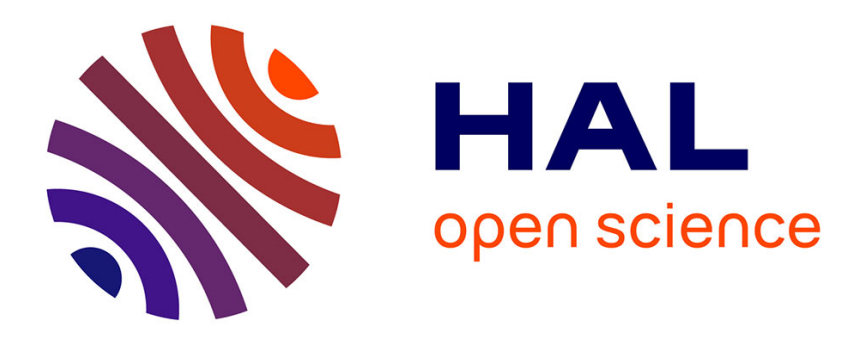

\title{
Multiple Representations of Human Genetics in Biology Textbooks
}

Pierre Clément, Jérémy Castéra

\section{To cite this version:}

Pierre Clément, Jérémy Castéra. Multiple Representations of Human Genetics in Biology Textbooks. D.F. Treagust and C.-Y. Tsui. Multiple Representations in Biological Education, Springer, pp.147-164, 2014, Models and Modeling in Science Education, 7. hal-01026089

\section{HAL Id: hal-01026089 \\ https://hal.science/hal-01026089}

Submitted on 19 Jul 2014

HAL is a multi-disciplinary open access archive for the deposit and dissemination of scientific research documents, whether they are published or not. The documents may come from teaching and research institutions in France or abroad, or from public or private research centers.
L'archive ouverte pluridisciplinaire HAL, est destinée au dépôt et à la diffusion de documents scientifiques de niveau recherche, publiés ou non, émanant des établissements d'enseignement et de recherche français ou étrangers, des laboratoires publics ou privés. 
Clément P. \& Castéra J., 2013 - Multiple representations of human genetics in biology textbooks. In D.F. Treagust and C.-Y. Tsui (eds.), Multiple Representations in Biological Education. Springer, Models and Modeling in Science Education, 7 (pp.147-164), DOI 10.1007/978-94-007-4192-8_9, \# Springer Science+Business Media B.V.

\title{
Multiple Representations of Human Genetics in Biology Textbooks
}

(PrePrint, before corrections)

\author{
Pierre Clément $^{1}$ and Jérémy Castéra ${ }^{1 \& 2}$ \\ ${ }^{1}$ University Lyon 1, France \\ ${ }^{2}$ University Lyon 1, France/ University of Tartu, Estonia
}

Pierre Clément

S2HEP, University Lyon 1, France

University Lyon 1, 38 bd Niels Bohr, 69622 Villeurbanne Cedex, France

Pierre.Clement@univ-lyon1.fr, clement.grave@,free.fr

Jérémy Castéra

University of Tartu, Science Education Centre, Tähe 4-312, Tartu 51010, Estonia (Eesti), jeremycastera@gmail.com 


\begin{abstract}
Multiple ways of representing the emerging new genetic knowledge and its implications have resulted from recent research including the Human Genome Project. In this chapter, we discuss that the presentation of human genetics is now less deterministic, formulated in a more systemic approach, taking into account the interaction between the genes and their environment (epigenetics), discussing the notion of biological determinism, and including connections with ethical and social implications. How are these new genetic trends represented today in biology textbooks? Do multiple ways exist across cultures, languages, and countries? Two complementary sets of data are presented and discussed: (1) the representation of human genetic diseases in French biology textbooks, showing a frequent absence of a systemic approach with nevertheless some exceptions; and (2) a comparative analysis of biology textbooks in 16 countries, showing the common similarity in their use of an implicit message through the same clothes and hairstyle of identical twins, but strong differences-in their use of the metaphor genetic program-which depended on the sociocultural context of each country. We argue that the renewal of the taught representations of human genetics is not only correlated with the renewal of scientific knowledge, but also with implicit values underlying each country's sociocultural context.
\end{abstract}

Keywords: Epigenetics; Genetic determinism; International comparison; Metaphor; Textbooks 


\section{Introduction: Different Representations of the Genetic Determinism}

For many years, the teaching of genetics has only been centered on the determinism of the phenotype by the genotype as shown in Figure 1.

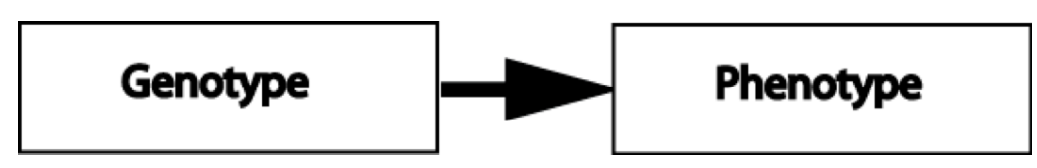

Figure 1. The most common representation of genetic determinism

This linear and deterministic representation is important in explaining what genetics is but is limited and even dangerous, at least in human biology and more generally. The human phenotype includes not only the anatomy and physiology of any person, but also his/her appearance built during his/her life; his/her illnesses and health; and his/her behavior, emotions, intelligence, skills, and any other learned competence. Most of these features are sociocultural and cannot be reduced to genetic determinism. For the learner, these ideas must be introduced in a more systemic manner. This does not mean that the genome is not important in explaining some phenotypic aspects, but to reduce all the phenotypes to a genetic influence is more ideological than scientific, expressing innatist ideas, namely, hereditarianism.

Several works illustrate the danger of this deterministic reductive representation. For instance, to justify sexism a sociological analysis showed the imprinting of innatist values (Nelkins \& Lindee, 1995). These authors suggested a parallel between DNA and the soul: Today, these are the genes that allow [us] to talk about personality traits, the nature of immortality, and the sacred meaning of life, in a way that resembles that of religious narratives [...]. DNA took in mass culture, the aspect of an entity similar to the soul. (p. 67) 
Other authors, in biology or in epistemology of biology, developed the idea that genes take the place of God to explain the determinism of human behavior and performances, and that the genetic program is a kind of predestination by God: everything happening was written in advance (Clément \& Castéra, 2007; Kupiec \& Sonigo, 2000; E. F. Keller, 2003).

Innatist ideas were very strong during the first half of the $20^{\text {th }}$ century, with a large extension of the Nazis' ideology. During this period, the research in genetics was growing and being structured in France into institutes of genetics and eugenics. More recent workssuch as those of the psychologists J. Keller (2005) in Germany, or Dambrun, Kamiejski, Haddadi, and Duarte (2009) in France - showed that, even today, differences among genres or ethnic groups are often justified by this deterministic representation of genetics, which is therefore linked to sexism and racism.

The idea of environmental influence on human phenotypes and performances became nevertheless more and more accepted during the $20^{\text {th }}$ century. Consequently, the traditional debate nature VERSUS nurture was progressively replaced by a new representation nature AND nurture. Percentages of contributions from both genotype and environment were proposed, for instance, to explain intelligence from research on twins (see the famous fraud of Burt reported by Lewontin, Rose, \& Kamin. 1984). This additional representation (genes + environment, see Figure 2) is still very popular in students' conceptions (e.g., Lewis, Leach, \& Wood-Robinson, 2000; Lewis, 2004) and even in school textbooks and teachers' conceptions (Clément \& Forissier, 2001; Forissier \& Clément, 2003). 


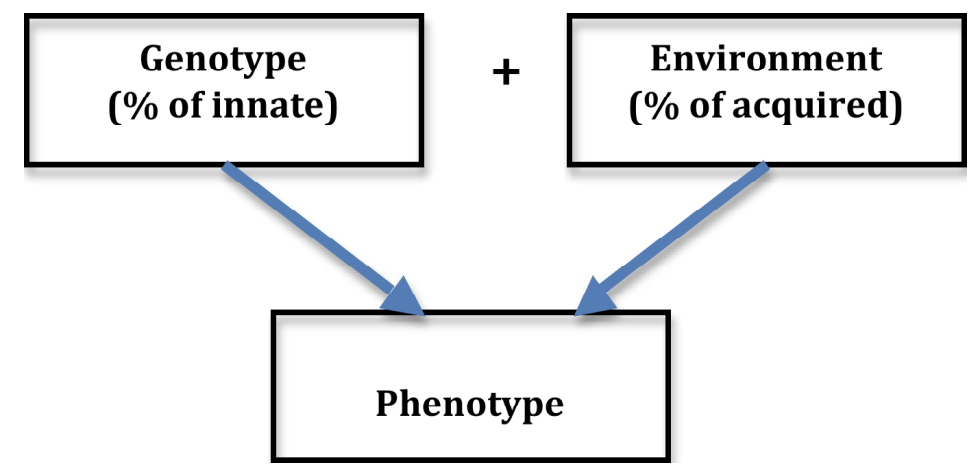

Figure 2. The additive representation of the genetic determinism (genotype + environment)

Nevertheless, this representation is scientifically incorrect because the genes and their environment cannot be added; rather they interact, as has been demonstrated by researchers in genetics (e.g., Jacquard, 1972). What is the part played by each in the development of the heart, the brain, or the liver in our body? When the genotype and the environment interact, it is impossible to evaluate their importance by a percentage. All biologists agree with an interactive representation shown in Figure 3 (e.g., Atlan, 1999; Jacquard \& Kahn, 2001; Lewontin, 2000).

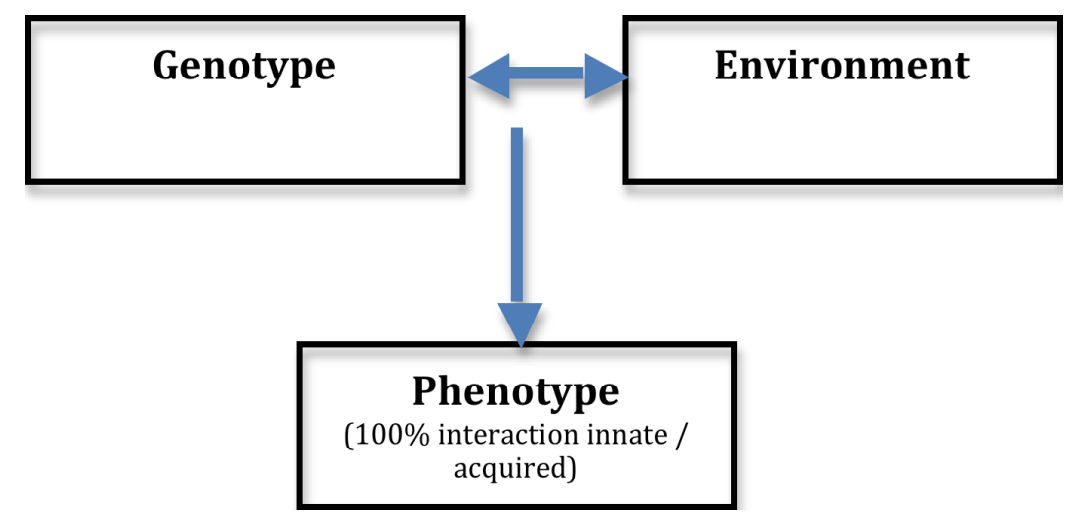

Figure 3. The interactive representation of the genetic determinism (genotype in interaction with environment) 
However, the interaction can be more complex than that in the representation in Figure 3, as for example, Lewontin's (2000) description in Triple Helix: Genes, Organism and Environment. Similarly, Forissier and Clément (2003) described three levels of interaction (see Figure 4):

(1) between the genes and their environment (epigenetics)(see Figure 5);

(2) between the phenotype and its environment, for example, when one has an accident resulting in amputation of one's leg; and

(3) between (1) and (2), for example, genetic manipulation or the use of a diet without phenylalanine to correct the effects of the gene mutation that causes phenylketonuria (Jacquard, 1972).

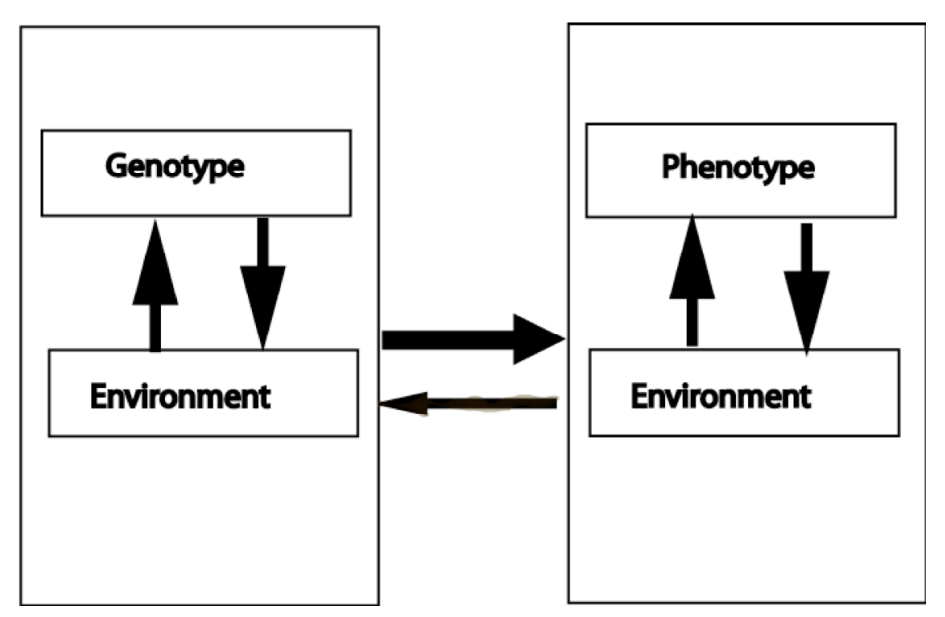

Figure 4. Interactive representation with three levels of interaction (adapted from Forissier \& Clément, 2003)

Since the late 20th century, the reductionist representation of genetic determinism — all by the genes - has declined (Atlan, 1999), giving more and more importance to the theories of complexity (Atlan, 1979; Morin 1990) with the new paradigms of emergence (Stengers, 1997) and epigenetics (Wu \& Morris, 2001; Morange, 2005a, 2005b). The interaction 
between the genes and their environment (see Figures 3 and 4) is now accepted by the scientific community opening a postgenomic period that follows the limited information from human DNA sequencing. The main results of the Human Genome Project were first published in the special issues of Nature and Science in February 2001. Most authors have insisted on the importance of interactions between several levels of biological organisation, with DNA being one of these levels (Lewontin, 2000; Képès, 2005; see Figure 5). Nevertheless, there are two kinds of definition and representation of epigenetics (see Figure 5).

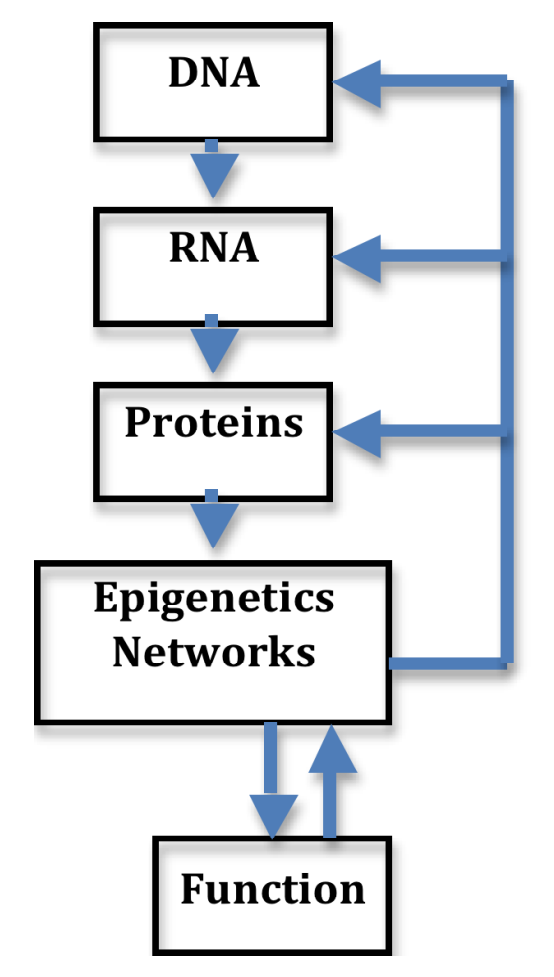

(1)

Figure 5. Epigenetic feedback loops. Epigenetics sensu stricto (1) is the feedback involving DNA (e.g., methylation, histones acetylation etc.). Epigenetics sensu largo (2) involves all the levels of feedback. At each level there is an interaction between a biological organisation and its environment (modified from Atlan, 1999). 
The strict scientific definition of epigenetics (Pouteau, 2007, p.155) is only concerned with the control of the activity of genes by chemical modifications of the DNA itself (e.g., by methylation) or of proteins of the chromatin around the DNA (e.g., histones acetylation). A broader definition of epigenetics is concerned with all the nongenetic processes which, in interaction with the genes, are acting to build a phenotype. This last definition does not differ from the notion of epigenesis used during the $17^{\text {th }}$ century against the preformationist ideas, and was used again in the 1940s by Waddington for the nongenetic processes by which the phenotype is emerging (for Waddington, "epigenesis + genetics = epigenetics") (Van Speybroek, 2002). The human cerebral epigenesis is a possible illustration of this kind of emergence, by interaction between the human genes (as the basis of the cerebral ontogenesis) and other processes such as selection of neural networks by individual activity—natural selection of synapses (Changeux, 1983) and neural Darwinism (Edelman, 1987).

More generally, the concepts of determinism or instructions are much debated today in biology. The alternative representation, from the consensual schema of the Darwinian theory of evolution (see Figure 6), shows that several different structures, coming from processes of differentiation, are selected by their interaction with the environment and only the most adapted ones survive. This schema is documented for the cerebral epigenesis, with a first step of having redundant innervations, some of which are then selected for differentiation when they become functional depending on the activity of the organism (Changeux, 1983; Edelman, 1987). More recently, this same schema exists for embryology and cellular differentiation, namely, cellular or molecular Darwinism (Kupiec, 2008, 2009; Paldi \& Coisne 2009; Kupiec, Gandrillon, Morange, \& Silberstein, 2009; Gayon, 2009).

In all these cases, stochastic processes are very important for the differentiation, even if they are in interaction with the pre-existing biological structures. For instance, a mutation can be stochastic but dependent on the pre-existing gene. Similarly, the first redundant synapses 
can be stochastic but the functional synapse depends on the interaction between cells in a precise location and so on. The same stochastic processes exist in molecular and cellular biology for understanding cell differentiation, embryology, and other biological processes. Cell differentiation results from the general schema, shown in Figure 6, of an interaction between stochastic processes and biological pre-existing structures.

In consequence, any determinism seems to be a special case of a probabilistic phenomenon though the regularity of such emergence is not in contradiction with the stochastic processes. For instance, when tossing a coin, each event (head or tail) is totally stochastic, but is regularly 50\% / 50\% after a thousand tosses for a fair coin.

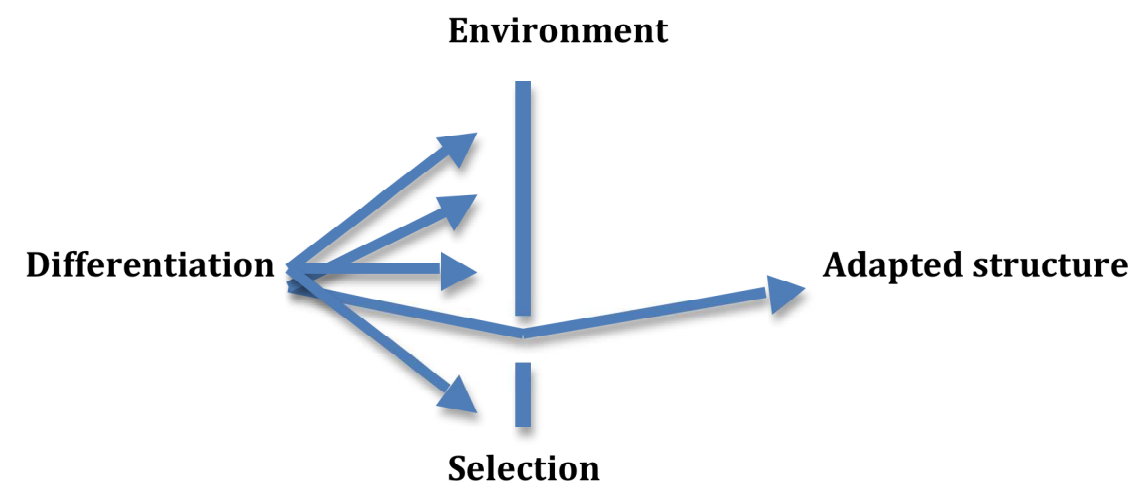

Figure 6. Darwinian selection as an alternative to the biological determinism.

To summarize this part, Figures 1 to 6 illustrate possible multiple representations of genetic determinism. The additive representation in Figure 2 is out of date because it is in contradiction with the process of interaction. Nevertheless, the other representations are never totally false. For instance, causal determinism of phenotype by genotype in Figure 1 is often used by researchers who try to identify the genetic determinism of a precise feature; however, this procedure is dangerous and scientifically wrong when it reduces any feature, and particularly any sociocultural human feature, to genetic determinism. Moreover, any research in biology today focuses on the analysis of greater complexity more with a systemic approach 
including interaction between biological structures, between them and their environment, and also with stochastic processes.

The social challenges of these scientific debates about multiple representations of human genetics are very important for improving health as well as for arguing against fatalism and exclusion of citizenship based on sexism or racism. The dangers of innatist ideas have been stated by researchers in several countries - for instance, in the USA, by Lewontin et al. (1984), Lewontin (2003), Beckwith (1993), Gould (1997); in the UK, by Rose et al. (1977); in France, by Jacquard (1972), Clément, Blaes, and Luciani (1980), Stewart (1993), Atlan (1999), Kupiec and Sonigo (2000), Clément and Forissier (2001), Jacquard and Kahn (2001), Séralini (2003), and others.

In the second part of this chapter, we analyze the multiple representations of genetic determinism and discuss the related issues from two sets of data: (1) an analysis of genetic diseases in French textbooks; and (2) an analysis of two indicators of genetic determinism (photos of human twins and the metaphor genetic program) in biology textbooks of 16 countries.

\section{An Analysis of Genetic Diseases in French Textbooks}

Human genetic diseases are frequently used as examples in chapters on genetics in French secondary school textbooks. But the choice of a particular example over another can significantly impact the message to the learner. For this reason, we chose to list genetic disease examples found in chapters on genetics in school textbooks and to explore the way these examples are presented. Do they illustrate genetic determinism in a strict reductive sense (see Figure 1) or rather do they introduce more complexity and systemic approachshowing interactions between the genome and its environment (see Figures 3 and 4) - and 
possibly notions of epigenetics (see Figure 5) or debates on genetic determinism (see Figure $6)$ ?

Every human genetic disease is the result of interactions between the genotype and its environment (Chakavarti \& Little, 2003) even when they appear illustrative of a simple, linear model of genetic determination (see Figure 1). For example, in the case of phenylketonuria (a monogenic disease), a special diet can completely prevent the occurrence of mental retardation. Furthermore, a genetic disease represents a malfunctioning of or mutation in one or multiple genes, but is not always hereditary (Séralini, 2003). In our analyses, we separate genetic diseases into two large categories - monogenic diseases, caused by a mutation in a single gene, and polygenic diseases, where multiple genes play a role in symptom development (Swynghedauw, 2000). Our research addresses both monogenic and polygenic diseases as well as chromosomal anomalies.

We analyzed 18 biology textbooks, published by four different French publishers, containing chapters dealing with human genetics (Castéra, Bruguière, \& Clément, 2008). As genetics is only taught in the last four years of secondary education in France (i.e., students aged 15-18 years), only these school levels were included in the study. The main results are now summarized in the following section.

The first result indicates that the examples of genetic diseases or anomalies present in the textbooks are not reflecting their prevalence around the world. Monogenic diseases, which are rare, are the most represented (between $51 \%$ to $91 \%$ of examples, depending on the school level; see Table 1). For instance, cystic fibrosis affects 1 in 13,000 births in France ${ }^{1}$. Even the

\footnotetext{
${ }^{1}$ Based on the online data from France's Centre d'Epidémiologie sur les causes médicales de décès (CéPiDc) at: http://www.invs.sante.fr/surveillance/maladies_rares/mortalite mucoviscidose.htm (data retrieved in August
} 
chromosomal anomalies are relatively rare ( 1 in 800 births in France has Down syndrome ${ }^{2}$ ). On the other hand, polygenic diseases are much more frequent: one American in two and one European in three will develop a cancer during the course of his or her lifetime (Séralini, 2003). Also there were 177 million diabetic patients in the world in the year 2000 and, according to Shaw, Sicree, and Zimmet (2010), this figure was predicted to rise to 300 million by the year 2025 .

The prevalence of examples of monogenetic diseases probably corresponds to textbook authors' wish to present conceptual ideas as simply as possible for the youngest students (1415 year olds) - with the visual images of the chromosomes of the Down syndrome, the definition of a gene as a portion of chromosome, and then as a portion of DNA- while the definition of a gene is currently under debate (e.g., Chevassus-Au-Louis, 2001; J. Keller, 2003; Abrougui \& Clément, 2005)—and finally a clear example of a monogenetic disease such as Duchenne muscular dystrophy. Nevertheless, the danger of the choice of these examples is to deeply anchor the deterministic representation of Figure 1 in the students' minds.

More complexity is introduced to students of 15-16 years old, with nearly half of the examples dealing with polygenic diseases, and even sometimes with modulator genes. The main examples are diabetes (sometimes presented as monogenic in the previous school levels, but no more here) and half of the examples are cancers.

\footnotetext{
${ }^{2}$ Depending the age of the mother, from $1 / 1500$ (20 years old) to $1 / 100$ (40 years old) (Herman, A. et al. 2002)
} 
Table 1

Occurrences of Genetic Diseases by Both School Level and Type of Genetic Determinism in the School Textbooks Analyzed

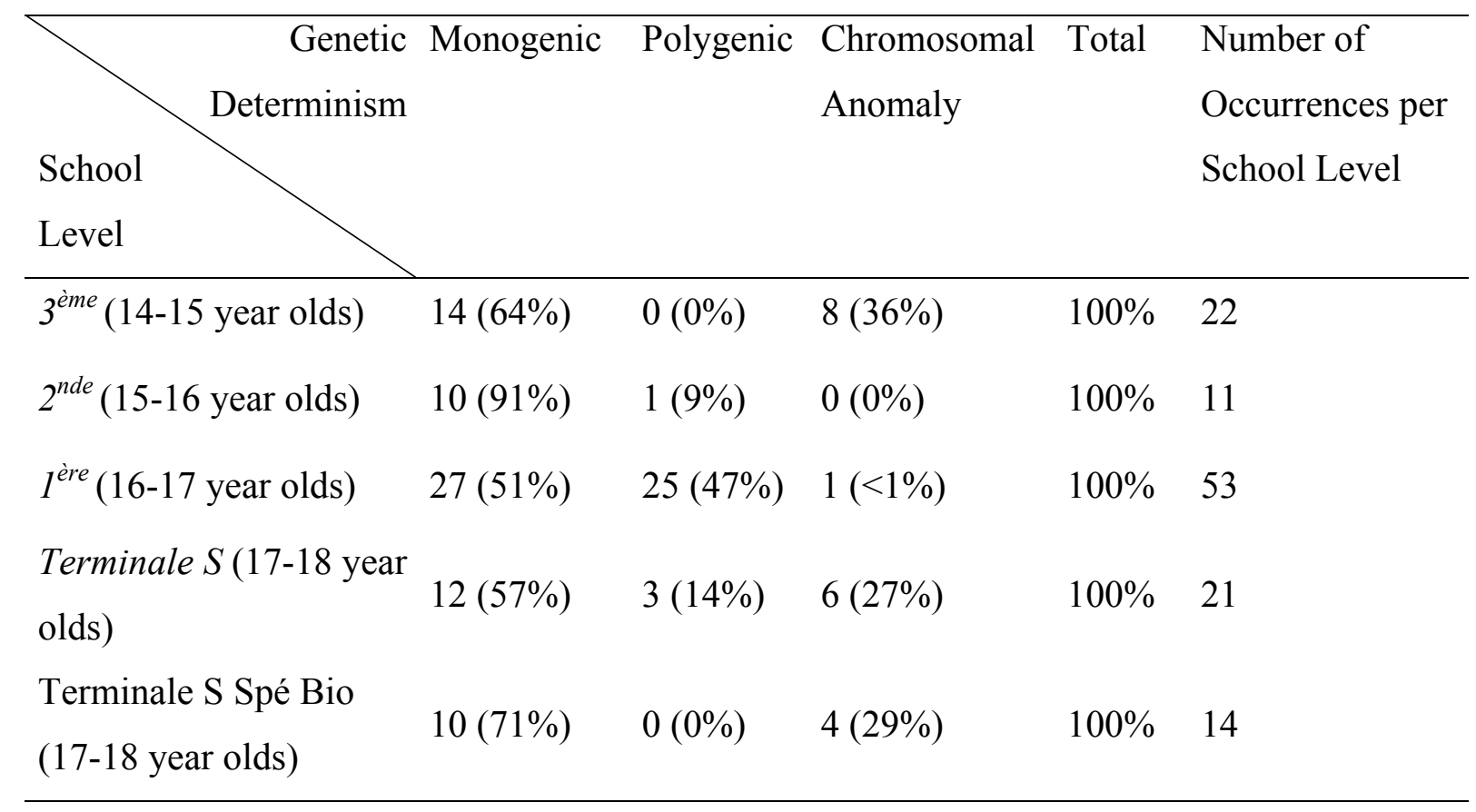

Environmental influence is rarely addressed in the School Level $3^{\text {ème }}$ and is included in no more than one-third of genetic disease examples presented in the textbooks for the School Levels, $2^{\text {nde }}, 1^{\text {ère }}$, and Terminale. These results demonstrate the predominance of simplistic, causal deterministic mechanisms of genetic diseases (see the representation in Figure 1) in the French secondary school textbooks studied. 
Table 2

Environmental Influence on Genetic Disease Examples

\begin{tabular}{|c|c|c|c|c|c|c|}
\hline School Level & $\begin{array}{l}3^{\text {ème }} \\
(14-15 \\
\text { year } \\
\text { olds })\end{array}$ & $\begin{array}{l}2^{\text {nde }} \\
(15-16 \\
\text { year } \\
\text { olds })\end{array}$ & $\begin{array}{l}1^{\text {ère }} \mathrm{S} \\
(16-17 \\
\text { year } \\
\text { olds })\end{array}$ & $\begin{array}{l}\text { Terminale } \\
S(17-18 \\
\text { year olds) }\end{array}$ & $\begin{array}{l}\text { Terminale } \\
\text { spécialité } \\
(17-18 \\
\text { year olds) }\end{array}$ & $\begin{array}{l}\text { Tota } \\
1\end{array}$ \\
\hline $\begin{array}{l}\text { (1) Number of occurrences } \\
\text { of genetic disease examples }\end{array}$ & 22 & 20 & 144 & 24 & 25 & 235 \\
\hline $\begin{array}{l}\text { (2) Number of occurrences of } \\
\text { genetic diseases mentioning } \\
\text { environmental influence }\end{array}$ & 3 & 6 & 49 & 6 & 4 & 68 \\
\hline $\begin{array}{l}\text { (2) Number of ... } \\
\text { environmental influence as } \\
\text { percentage of ( } 1 \text { ) number of ... } \\
\text { genetic diseases examples }\end{array}$ & $14 \%$ & $30 \%$ & $34 \%$ & $25 \%$ & $16 \%$ & $28 \%$ \\
\hline
\end{tabular}

However, diseases significantly influenced by environmental factors (e.g., diabetes, cancers) are relatively frequent in textbooks for 15-16 and 16-17 years old students. The presence of such examples contributes to a less simplistic representation of genetic determinism. As shown in Figure 7, the environment is mentioned in the discussion of cancers and diabetes in more than $50 \%$ of cases studied. In case of monogenic diseases or chromosomal anomalies, the environment can influence a disease by rendering the disease either partially reversible (e.g., by means of an adapted education in the case of Down syndrome) or completely reversible (e.g., in the case of phenylketonuria); however, environmental influence is rarely mentioned in French textbooks. Such representation is only justified for cystic fibrosis and Duchenne muscular dystrophy, both of which are strongly 
subject to monogenic determinism. With regard to Down syndrome, only one textbook (Bordas publisher, level "Terminale scientifique”) (Castéra, Bruguière, et al. 2008) makes reference to environmental factors capable of influencing the disease, by clearly indicating that an education program may allow better integration of Down syndrome patients in society.

This under-representation of the environmental influence in the examples of genetic diseases is consistent with the biomedical model of health predominating in French biology textbooks. In contrast, textbooks from other countries are more focused on the model of health promotion (Carvalho et al., 2008).

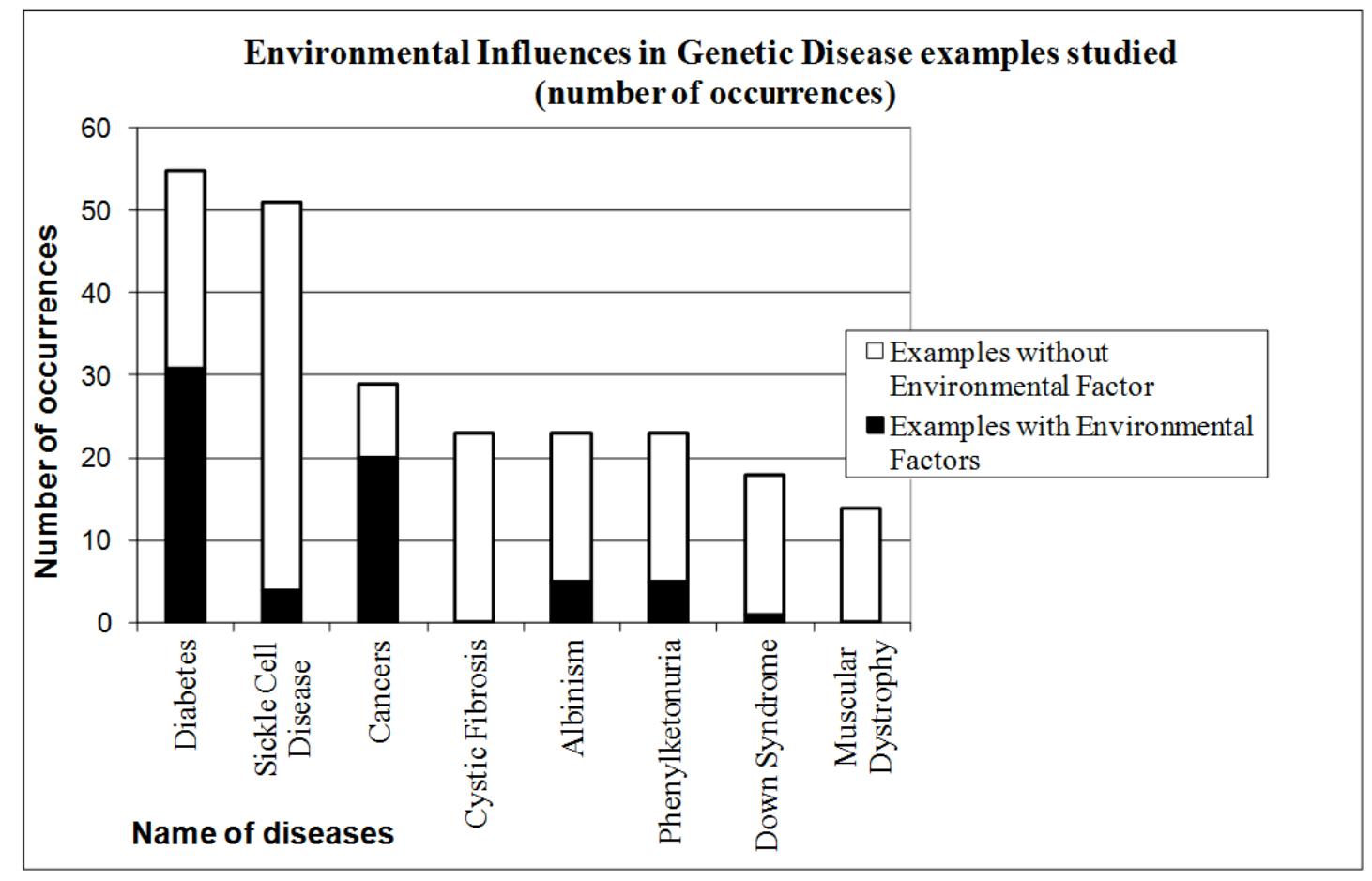

Figure 7. Environmental influence in ten genetic disease examples in the analyzed French textbooks.

A final point is that not even one of the analyzed textbooks contained the word epigenetics, nor any one explained its content. Further, there was no debate on the notion of genetic determinism and no mention of the possible alternatives as shown in Figure 6. These new 
concepts and representations of the human genetics were too recent (1999 to 2005) to be introduced in the analyzed textbooks (published between 2001 and 2004). The Didactic Transposition Delay (DTD) - the time between the scientific publications and their introduction in syllabuses and textbooks (Quessada \& Clément, 2007)—is longer, and we hope these new representations will be present in the more recently published textbooks.

Nevertheless, important advancements have been made since publication of the previous French curricula and biology textbooks in 1995 toward a less simplistic presentation of the causes of genetic diseases - no longer only limiting these diseases to a single gene (that was totally dominant in the previous textbooks; see Abrougui, 1997). In the new syllabuses, multiple genes, as well as the interaction between the genome and its environment, are presented. Complex determinism models for diseases (such as cancers or diabetes) help to prevent students' minds from being ingrained with the single, oversimplified conception of genetics, which nevertheless continues to predominate in biology textbooks.

\section{Images of Twins and the Metaphor Genetic Program in Textbooks of 16 Countries.}

The results presented here come from research in the context of the project BIOHEADCitizen (Biology, Health and Environmental Education for Better Citizenship) (BIOHEADCitizen, 2004-2008). This research project included a comparison of the biology textbooks dealing with six selected topics, one of which is human genetics.

We analyzed 50 textbooks in 16 countries (with number of textbooks analyzed given in parentheses): Cyprus (2), Estonia (2), Finland (2), France (11), Germany (3), Hungary (3), Italy (7), Lebanon (4), Lithuania (2), Malta (2), Morocco (2), Poland (1), Portugal (4), Romania (1), Senegal (1), and Tunisia (3). The number of textbooks studied in each country differed because (i) in some countries, human genetics was taught at only one school level, whereas in other countries it was taught at two or more school levels; (ii) in some countries, 
there was only one official national publisher for school textbooks, whereas in others there were several private publishers. In the latter case, the most significant publishers were chosen. For each analyzed textbook, a long grid was completed. We present here only some results, dealing with two indicators.

\section{First Indicator: Photos of Human Twins}

Photographs are considered as scientific images because they convey a scientific message (Clément, 1996). In this specific case, the message is the morphological similitude of identical twins, which corresponds to the identity of their genotypes. In contrast, some images are intended to show morphological differences between fraternal twins. Nevertheless, the images of monozygotic twins - the same clothes, the same hairstyle, the same behavior and so on-can also have an implicit ideological message when they strongly suggest that features other than morphological ones can be genetically determined. Consequently, for each image of twins in the textbooks, we examined whether the twins were presented as having the same clothes, style and behavior; or, on the contrary, if the images showed differences illustrating the paradox of the twins-psychologists such as Zazzo (1984) showed that identical twins tend to differ in their psychological characteristics and sociocultural appearances. Identical twins are also a good illustration of possible epigenetic differences. For instance, Fraga et al. (2005) showed that in $35 \%$ of the monozygotic twins studied, there were differences in the methylation of their DNA and histones acetylation; these epigenetic differences are more important in the older twins and in twins with different lifestyle or medical history.

The results of the analysis are spectacular (Clément \& Castéra, 2007; Castéra \& Clément, 2007; Castéra et al., 2008). In all the images of identical twins in the textbooks, twins had exactly the same clothes, hairs, and so on (except one case where the color of the jacket was different, as well as the length of the hair), whereas the images clearly differ for the fraternal 
twins. Consequently, for all these images, the representation of genetic determinism corresponded to Figure 1 ("genotype $\rightarrow$ phenotype") with, moreover, implicit innatist ideas that are not scientifically correct, suggesting that the sociocultural features (e.g., clothes, hairstyle etc.) would be determined by the genes.

\section{Second Indicator: Occurrence of the Metaphor Genetic Program}

This hereditarianist expression genetic program now appears questionable. The deterministic representation of genetics (see Figure 1) suggesting that everything of our life is written in our DNA program - as a predestination written in the plan of God for some religions - is no longer accepted by biologists (Abrougui \& Clément, 1997; Atlan, 1999; Morel \& Miquel, 2001; Kupiec \& Sonigo, 2000; Clément \& Forissier, 2007; Noble, 2007). Consequently, Atlan (1999) and other authors proposed to replace genetic program by genetic information. Is the Didactic Transposition Delay (DTD) sufficient for observing a diminution or suppression of this expression genetic program in the analyzed textbooks? The results (see Table 3) showed important differences in using this expression among the textbooks of 16 countries. In the textbooks of some countries, the expression genetic program is very commonly used:

(1) The Maltese textbooks are in fact British textbooks published in 1986. At that time, the deterministic model was very popular in several countries (Abrougui, 1997). In these Maltese textbooks, the term genetic program was not used, but the same message was in the expression: "the DNA molecule forms a code which instructs the cell" (10 occurrences in a textbook and one occurrence in another textbook for 15-16 year olds) (see Table 3). The message is that the cells could simply follow these instructions to produce the phenotype, just like a program. 
Table 3

Total Occurrences of "Genetic Program" and Some Expressions with the Same Implicit Meaning

\begin{tabular}{|c|c|c|c|c|c|c|c|c|}
\hline Country & $\begin{array}{l}11-12 \\
\text { year } \\
\text { olds }\end{array}$ & $\begin{array}{l}12-13 \\
\text { year } \\
\text { olds }\end{array}$ & $\begin{array}{c}13-14 \\
\text { year } \\
\text { olds }\end{array}$ & $\begin{array}{l}14-15 \\
\text { year } \\
\text { olds }\end{array}$ & $\begin{array}{l}15-16 \\
\text { year } \\
\text { olds }\end{array}$ & $\begin{array}{l}16-17 \\
\text { year } \\
\text { olds }\end{array}$ & $\begin{array}{c}17-18 \\
\text { year } \\
\text { olds }\end{array}$ & $\begin{array}{r}18-19 \\
\text { year } \\
\text { olds }\end{array}$ \\
\hline Cyprus & & & & & 0 & & 0 & \\
\hline Estonia & & & & 0 & & 0 & & \\
\hline Finland & & & 17 & & & 53 & & \\
\hline France & & & & $\begin{array}{l}66-7 \\
*\end{array}$ & $\begin{array}{l}18- \\
49^{*}\end{array}$ & $1-2 *$ & $0-0$ * & \\
\hline Germany & & & & 0 & & & $0-0$ & \\
\hline Hungary & & & & & & 1 & $0-0^{*}$ & \\
\hline Italy & $0-0-0^{*}$ & & & $0-2-0-0$ & & & & \\
\hline Lebanon & & & 27 & & $3-0 * *$ & 1 & & \\
\hline Lithuania & & & & & 0 & & 1 & \\
\hline Malta & $\begin{array}{l}\text { No } \\
\text { textbook }\end{array}$ & & & & $10-1^{*}$ & & & \\
\hline Morocco & & & 23 & & & & 28 & \\
\hline Poland & & & & & & & 0 & \\
\hline Portugal & & & & 2 & & 2 & $0-1 * * *$ & \\
\hline Romania & & & & & & & 5 & \\
\hline Senegal & & & & & & & & 1 \\
\hline Tunisia & & & & 0 & & & 0 & 0 \\
\hline
\end{tabular}

* Occurrences in two or more textbooks from different publishers (figures separated by a hyphen).

** Occurrences in two textbooks from the same publisher but from science section or humanity section (figures separated by a hyphen).

*** Occurrences in one biology textbook and one psychology textbook in Portugal (figures separated by a hyphen). 
(2) In Finnish textbooks, we found a strong presence of the notion genetic program: 70 occurrences versus only five occurrences of genetic information in recently published textbooks (2004 and 2006). So even though the scientific community no longer uses the expression genetic program, the Finnish textbooks still do. In another work, we found a trend of the Finnish teachers' conceptions clearly correlated with the implicit metaphor genetic program (Castéra, Clément, \& Kosonen, 2009).

(3) In Portuguese textbooks, there is both a persistence of the notion of a genetic program with at least one occurrence by level, and an absence of a clear evolution between the various levels. A possible explanation in this case is the difficulty in changing the scientific and ideological content of the chapter on human genetics.

(4) In France, there are strong differences in the occurrences of this metaphor genetic program among the textbooks from three different publishers, and also across school levels (the higher the level, the fewer its use) and it completely disappears at the end of the curriculum. Compared to syllabuses and French textbooks published in the 1990s, the occurrence of the metaphor genetic program is very infrequent in today's textbooks, with this being increasingly replaced by the notion genetic information. Nevertheless, the disappearance of the term genetic program is not complete, suggesting the influence of other parameters. One parameter is pedagogical. Teachers start using genetic program for teaching the youngest students and progressively use genetic information more frequently. This initial simplification (to start with the message "genotype $\rightarrow$ phenotype") is educationally dangerous; Clément, Forissier, and Carvalho (2003) showed that the first concepts taught are those most memorized by students. The second parameter is the different strategies among the publishers. Thirdly, it is also possible that the difficulty of completely suppressing the notion genetic program was because that this was extremely central in the previous syllabuses. 
Therefore, the textbook authors and publishers still use this notion with a certain difficulty to change their traditional way of thinking.

(5) (6) (7) In Moroccan, Lebanese, and Senegalese textbooks, we found the same kind of results as in those in France, possibly indicating a French influence, but sometimes with delay. On the contrary some countries do not use, or else very rarely use, the metaphor genetic program in textbooks.

(8) Tunisian textbooks use only the concept of genetic information throughout the three school levels where human genetics is taught. The total absence of the use of genetic program is probably a consequence of the growing influence of Tunisian researchers in Didactics of Biology (Abrougui, 1997). Nevertheless, that does not yet mean a total disappearance of innatist ideas from the Tunisian textbooks (Clément, Mouehli, \& Abrougui, 2006), nor does it mean its disappearance from the Tunisian teachers' conceptions (Kochkar, 2007, 2010).

(9) In Germany, the metaphor genetic program is totally absent. As in other Western European countries and the USA, genetic research developed in eugenics institutes has the goal of building genealogical trees and tracking patterns of occurrence of diseases and disabilities (Wolf, 2002). According to O’Mahony and Schäfer (2005), the collective memory of the Nazis' eugenics program is an important background for not referring to a genetic program in communicating about human genetics.

(10) In Cyprus, the textbooks use exclusively genetic information: eight occurrences in the textbooks for 15-16 year olds and 17 occurrences in the textbooks for 17-18 year olds. The explanation is not easy: it can be an effect of the complex history of this country, as well as a desire to avoid using the metaphor of a computer program.

(11) In the Italian textbooks, the precise expression, genetic program, occurs only twice and just in one textbook. The textbooks generally use terms like hereditary patrimony and genetic patrimony which are more neutral than genetic program, with less implicit meaning. 
This could show the same desire as in Germany being cautious in dealing with hereditarianist ideology. The common past of Germany and Italy during the Second World War certainly had an influence on the way human genetics was taught, albeit sometimes awkwardly. For example, in one of the textbooks, the metaphor of the books of life is used. According to this metaphor of the book of life, it would be enough to know the alphabet and the genetic syntax to reach the essence of the human being. Today, such a conception is scientifically unacceptable and ethically dangerous.

(12) In the Lithuanian textbooks, there is just one occurrence that could be considered as a notion similar to genetic program: the reproduction of cells is programmed in genes, but there is never the precise expression: genetic program. In Lithuania, the explanation for this absence seems to be deeply rooted in the past: the notion was traditionally absent in the previous syllabuses and textbooks. We have verified this for textbooks published since 1979 .

(13) (14) (15) Estonia, Poland and Hungary are three other countries included in or influenced by the former Soviet Union, and their textbooks show the same trend as in Lithuania: no one mention of genetic program, but several mentions of genetic information. Only one exception was found in a Hungarian textbook with the term programmed by a gene (exactly the same expression quoted above in a Lithuanian textbook). Our hypothesis is that in these countries there was one official line to teach biology based on the work of Lysenko (Лысе́нко) and Michurin (Мичурин) in the former Soviet Union, with a negation of the idea of a genetic program, even if at the end of the 1960s, the pseudo-scientific, neo-Lamarckism ideas of Lysenko and Michurin were rejected. The role of DNA in hereditary information was then accepted and presented in all textbooks. However, without the idea of a genetic program, and the differences between human individuals were also always explained by environmental or social conditions. 
(16) Romania also was formerly influenced by the Soviet Union; we found five occurrences of genetic program and 19 occurrences of genetic information in the unique Romanian textbook, dealing with human genetics (with only 13 pages devoted to this topic).

In conclusion, there were contrasting results from the biology books used in these 16 countries. In each country's textbooks, the representations of identical twins were linked not only to a scientific message (morphological resemblance correlated with the same genome) but also to an implicit ideological message (a suggested genetic determinism of sociocultural features such as clothes or hairstyle). This kind of social representation of identical twins, deeply anchored in nonscientific ideologies, is in contradiction with the renewal of scientific knowledge in human genetics, such as the importance of epigenetic processes in explaining differences even between monozygotic twins.

On the contrary, there were interesting differences among the 16 countries in terms of the use in their textbooks of the metaphor genetic program, which was sometimes replaced by another deterministic metaphor book of life. Language is never neutral and the expression genetic information is less ideological than genetic program, less deterministic and more open to interactions with environmental and epigenetic processes from a systemic perspective. We suggest several hypotheses to explain the occurrence (or absence) of the metaphor genetic program in each of these 16 countries. They illustrate interactions between science (the taught science) and society (its history and other characteristics), as well as ethical, cultural, and social implications of this use, and interactions between the taught scientific knowledge (K) with implicit values (V) and social practices (P) — the KVP model (Clément, 2004, 2006). As a general conclusion, the multiple representations of human genetic determinism in school textbooks not only correspond to the renewal of the scientific knowledge in human genetics but are also correlated with sociocultural parameters, values, and, social practices, which differentiate the way by which human genetics is taught in different countries. 


\section{Acknowledgments}

This research was financed by the BIOHEAD-Citizen project (2004-2008): Biology, Health and Environmental Education for Better Citizenship (E.C., STREP n CIT2-CT2004-506015, FP6, Priority 7). We would like to thank our colleagues from the 16 countries who, in the context of this project, analyzed the textbooks of their country and provided us with the results for writing this chapter.

\section{References}

Abrougui, M. (1997). La génétique humaine dans l'enseignement secondaire en France et en Tunisie. [Human genetics in secondary schools, in France and in Tunisia]. Thèse Doctorat Université Lyon 1, France.

Abrougui, M., \& Clément P. (1997). Enseigner la génétique humaine: citoyenneté, ou fatalisme ? [Teaching human genetics: Citizenship or fatalism?]. In A. Giordan, J.-L. Martinand, D. Raichvarg (éd.), Actes JIES 19e Journées internationales sur l'éducation scientifique. [International days on science education](pp. 255-260). Chamonix, Université Paris Sud.

Abrougui, M., \& Clément P. (2005). Two strategies to introduce genetics in Tunisian and French textbooks. Proceedings of the Fifth International ESERA Conference on Contributions of Research to Enhancing Students' Interests in Learning Science. Barcelona (Spain), pp. 1245-1249.

Atlan, H. (1979). Entre le cristal et la fumée: essai sur l'organisme vivant [Between crystal and smoke: An essay on the living organism]. Paris: Seuil.

Atlan, H. (1999). La fin du "tout génétique" [The end of "everything is genetic"]. Paris: INRA. 
Beckwith, J. (1993). A historical view of social responsibility in genetics. BioScience, 43(5), 327-333.

BIOHEAD-Citizen (2004-2008). Biology, Health and Environmental Education for Better Citizenship. In G. Carvalho, P. Clément, \& F. Bogner (Eds.) European Research Project (Specific Targeted Research n CIT2-CT2004-506015, FP6, Priority 7) http://projectos.iec.uminho.pt/projeuropa/

Carvalho, G.S., Dantas, C., Rauma A.-L., Luzi D., Bogner F., Caussidier C., Clément P. (2008). Comparing health education approaches in textbooks of sixteen countries. Science Education International, 19(2), 133-146.

Castéra, J., Bruguière C., \& Clément P. (2008). Genetic diseases and genetic determinism models in French secondary school biology textbooks. Journal of Biological Education, 42(2), 53-59.

Castéra, J., \& Clément, P. (2007). Hereditarianism and reductionism in biology school textbooks, through images of twins. A comparative study between 15 countries. Proceedings of ESERA (European Science Education Research Association). Malmö (Sweden), 4 p. (CD-ROM).

Castéra, J., Clément, P., Abrougui, M., Sarapuu, T., Turcinaviciene, J., Agoram, B., ...Carvalho, G.S. (2008). Genetic Determinism in school textbooks A comparative study conducted among 16 countries. Science Education International, 19(2), 163184.

Castéra, J., Clément, P., \& Kosonen, A-L. (2009). The genetic determinism of human performances. A comparison between teachers' conceptions in Finland and France. Conference ESERA (European Science Education Research Association). Istanbul.

Chakavarti, A., \& Little, P. (2003). Nature, nurture and human disease. Nature, 421, 412-414.

Changeux, J. P. (1983). [L'homme neuronal The neuronal man]. Paris: Fayard. 
Chevassus-Au-Louis, N. (2001). Dix-huit facettes d'un même concept [Eighteen facets of the same concept]. La Recherche, 348, 51- 56.

Clément, P. (1996). L'imagerie biomédicale: définition d'une typologie et proposition d'activités pédagogiques [Biomedical imagery: Definition of a typology and proposition of pedagogical activities]. Aster, 22, 87-126.

Clément, P. (2004). Science et idéologie: exemples en didactique et épistémologie de la biologie [Science and ideology: Examples in didactics and epistemology of biology]. Actes du colloque "Sciences, médias et société » [Proceedings of the Conference "Sciences, media and society"], Lyon, ENS LSh (Laboratoire Communication, Culture et Société), pp. 53-69. Available: http://sciences-medias.ens1sh.fr/IMG/pdf/actes.pdf.

Clément, P. (2006). Didactic Transposition and the KVP Model: Conceptions as Interactions Between Scientific Knowledge, Values and Social Practices. Proceedings Summer School ESERA. IEC, Univ. Minho (Portugal), pp. 9-18.

Clément, P. (2007). Introducing the cell concept by both animal and plant cells: a historical and didactic approach. Science \& Education, 16, 423-440.

Clément, P., Blaes N., \& Luciani, A. (1980). Le mythe tenace du "chromosome du crime", encore appelé "chromosome de l'agressivité" [Persistent myth of the "chromosome of crime", also called “chromosome of aggressiveness"]. Raison Présente, 54, 109-127.

Clément, P., \& Castéra, J. (2007). L’Actualité des images de vrais jumeaux dans les magazines de vulgarisation et dans les manuels scolaires [Pictures of identical twins in popular magazines and in school textbooks]. In A. Giordan, J. L. Martinand, D. Raichvarg, Actes JIES (Journées Internationales sur la Communication, l'Éducation et la Culture Scientifiques et Industrielle) [International Days on Science Education],)(. Chamonix, 6 p., CD-ROM. 
Clément, P., \& Forissier, T. (2001). L’identité biologique n'est pas que génétique : un défi pour un enseignement citoyen [The biological identity is not only genetic: A challenge for a citizenship teaching]. Communication au Symposium BioEd 2000: The challenge of the Next Century. Paris, pp. 15-18, available: www.iubs.org/cbe/pdf/clement.pdf.

Clément, P., Forissier, T., \& Carvalho, G.S. (2003). The structuring influence of first images on the construction of science concepts. An historical and didactical approach. Acts of the 4th ESERA Conference. Noordwijkerhout (Netherlands), CD-ROM.

Clément, P., Mouehli, L., \& Abrougui, M. (2006). Héréditarisme, béhaviorisme, constructivisme: le système nerveux dans les manuels scolaires français et tunisiens [Hereditarianim, behaviorism, constructivism: Nervous system in French and Tunisian school textbooks]. Aster, 42, 187-222.

Dambrun, M., Kamiejski, R., Haddadi, N., \& Duarte, S. (2009). Why does social dominance orientation decrease with university exposure to the social sciences? The impact of institutional socialization and the mediating role of "geneticism'. European Journal of Social Psychology, 39(1), 88-100.

Edelman, G. (1987). Neural Darwinism: The theory of neuronal group selection. New York: Basic Books.

Forissier, T., \& Clément, P. (2003). Teaching "biological identity" as genome / environmental interactions. Journal of Biological Education, 37(2), 85-91.

Fraga, M. F., Ballestar, E., Paz, M.F., Ropero, S., Setien, F., Ballestar, M.L., ... Esteller, M. (2005). Epigenetic differences arise during the lifetime of monozygotic twins. Proceedings of the National Academy of Sciences of the USA, 102, 10604-10609.

Gayon, J. (2009). Déterminisme génétique, déterminisme bernardien, déterminisme laplacien [Genetic determinism, Bernard's determinism, Laplace's determinism]. In J.-J. Kupiec O., Gandrillon M., Morange \& M. Silberstein, Le hasard au cour de la cellule, 
probabilité, déterminisme, génétique [Chance at the heart of the cell, probability, determinism, genetics]. (pp. 79-91). Paris: Syllepse,.

Gould, S. J. (1997). Darwin et les grandes énigmes de la vie (Darwin and the great mysteries of life) (éd. originale: 1977). Paris: Seuil.

Herman, A, Dreazen, E, Herman, A. M., Batukan, C.E., Holzgreve, W., \& Tercanli S. (2002). Bedside estimation of Down syndrome risk during first trimester ultrasound screening. Ultrasound in Obstetrics \& Gynecology, 20(5), 468-475.

Jacquard, A. (1972). Eloge de la différence: La génétique et les hommes [In praise of difference: Genetics and human affairs]. Paris: Seuil.

Jacquard, A., \& Kahn, A. (2001). L'avenir n'est pas écrit [The future is not written]. Paris: Bayard.

Keller, E. F. (2003). Le siècle du gène [The century of the gene]. Paris: Gallimard.

Keller, J. (2005). In genes we trust: The biological component of psychological essentialism and its relationships to mechanisms of motivated social cognition. Journal of Personality and Social Psychology, 88, 686-702.

Képès, F. (2005). L'épigénétique comme aspect de la post génomique [Epigenetics as an aspect of post-genomics]. Medecine/Science, 21, 371-376.

Kochkar, M. (2007). Les déterminismes biologiques. Analyse des conceptions et des changements conceptuels consécutifs à un enseignement sur l'épigenèse cérébrale chez des enseignants et des apprenants tunisiens [Biological determinism: Analysis of Tunisian teachers' and learners' conceptions and conceptual changes resulting from education on cerebral epigenesis]. Thèse Doctorat Université Lyon 1 \& ISEFC Université de Tunis. 
Kochkar, M. (2010) Enseigner des valeurs ou des connaissances? L'épigenèse cérébrale ou le "tout génétique" [Teaching values or knowledge? Cerebral epigenesis or "all genetics"]. Saarbrücken, Germany: Editions Universitaires Européennes.

Kupiec, J.-J. (2008). L'origine des individus [The origin of individuals]. Paris: Fayard.

Kupiec, J.-J. (2009). Le hasard au cœur de la vie. Les gènes jouent-ils aux dés ? [Chance at the heart of life: Genes do they play at dice?]. La Recherche, 434, 51-53.

Kupiec, J.J., Gandrillon O., Morange, M., \& Silberstein, M. (2009). Le hasard au cæur de la

Cellule. Probabilité, déterminisme, génétique [Chance at the heart of the cell. Probability, determinism, genetics ]. Paris: Editions Syllepse.

Kupiec, J.-J., \& Sonigo P. (2000). Ni Dieu, ni gène [Neither God, nor gene]. Paris: Seuil.

Lewis, J. (2004). Traits, genes, particles and information: Re-visiting students' understandings of genetics. International Journal of Science Education, 26, 195-206.

Lewis, J., Leach J., \& Wood-Robinson, C. (2000). All in the genes? Young people's understanding of the nature of genes. Journal of Biological Education, 34, 74-79.

Lewontin, R. C. (2000), The triple helix, Cambridge, MA, Harvard University Press.

Lewontin, R. C., Rose S., \& Kamin, L.J. (1984). Not in our genes: Biology, ideology and human nature. New York: Pantheon.

Morange, M. (2005a). L'épigénétique: un domaine aux multiples facettes [Epigenetics: a multifaceted field]. Medecine/Science, 21, 339.

Morange, M. (2005b). Quelle place pour l'épigénétique? [What place for epigenetics?] Medecine/Science, 21, 367-369.

Morel, M.C., \& Miquel, P.A., (2001). Programme génétique: concept biologique ou métaphore? [Genetic program: biological concept or metaphor?]. Paris: éditions Kimé. 
Morin, E. (1990). Introduction à la pensée complexe [Introduction to complex thought]. Paris: ESF.

Nelkins, D., \& Lindee, M.S. (1995). The DNA mystique: the gene as a cultural icon. New York: Freeman.

Noble, D. (2007). La musique de la vie. La biologie au-delà du génome [The music of life: Biology beyond the genome]. Paris: Seuil.

O’Mahony, P., \& Schäfer, M. S. (2005). Comparing German and Irish Media Discourse on Human Genome Research. Journal of Social Studies of Science, 35 (1), 99-130.

Pàldi, A., \& Coisne, S. (2009). La fin du déterminisme en biologie [The end of determinism in biology]. La Recherche, 434, 40-44.

Pouteau, S. (2007). Génétiquement indéterminé - Le vivant auto-organisé [Genetically undetermined: The auto-organization of life]. Versailles: Quae.

Quessada, M.P., \& Clément, P. (2007). An epistemological approach to French syllabi on human origins during the 19 th $\& 20$ th centuries. Science \& Education, 16 (9-10), 9911006.

Rose, H., Rose, S., Hanmer, J. Enzensberger, H.M., Franck, R., Lévy-Leblond, J.M., \& Stéhelin L., (1977). L'idéologie de / dans la science [Ideology of / in science]. Paris: Le Seuil.

Shaw J.E., Sicree R.A., Zimmet P.Z., (2010). Global estimates of the prevalence of diabetes for 2010 and 2030. Diabetes Research and Clinical Practice, 87: 4-14

Séralini, G.E. (2003). Génétiquement incorrect [Genetically incorrect]. Paris: Flammarion.

Stengers, I. (1997). La Vie et l'Artifice: les visages de l'émergence [Life and Artifice: Faces of the emergence]. Cosmopolitiques.VI Paris: La Découverte.

Stewart, J. (1993). Au delà de l'inné et de l'acquis [Beyond the innate and the acquired]. Intellectica, 16, 151-174. 
Swynghedauw, B. (2000). Biologie et génétique moléculaire [Biology and molecular genetics]. Paris: Dunod.

Van Speybroeck, L. (2002). From epigenesis to epigenetics: The case of C. H. Waddington. Annals of New York Academy of Sciences. 981, 61-81.

Wolf, N. (2002). Krankheitsursachen Gene. Neue Genetik und Public Health [Genes and causes of disease: New genetics and public health]. Publications series of the research unit Public Health Policy Wissenschaftszentrum Berlin für Sozialforschung. Berlin, http://bibliothek.wzb.eu/pdf/2002/p02-202.pdf.

Wu, C.T., \& Morris, J. (2001). Genes, genetics, and epigenetics: A correspondence. Science, 293, 1103-1105.

Zazzo, R. (1984). Le Paradoxe des jumeaux [The twins paradox]. Paris: Stock. 